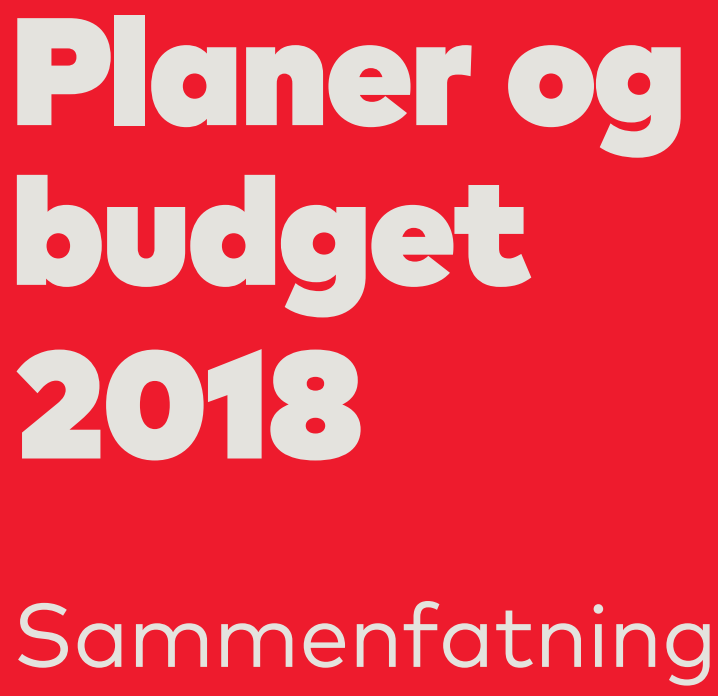

III) Nordisk

Ministerråd 


\section{Planer og budget 2018 - sammenfatning}

ANP 2018:724

ISBN 978-92-893-5415-8 (PRINT)

ISBN 978-92-893-5416-5 (PDF)

ISBN 978-92-893-5417-2 (EPUB)

http://dx.doi.org/10.6027/ANP2018-724

(c) Nordisk Ministerråd 2018

Layout: Erling Lynder

Tryk: Rosendahls

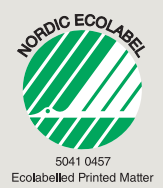

Printed in Denmark

\section{Det nordiske samarbejde}

Det nordiske samarbejde er en af verdens mest omfattende regionale samarbejdsformer. Samarbejdet omfatter Danmark, Finland, Island, Norge og Sverige samt Færøerne, Grønland og Åland.

Det nordiske samarbejde er både politisk, økonomisk og kulturelt forankret og er en vigtig medspiller i det europæiske og internationale samarbejde. Det nordiske fællesskab arbejder for et stærkt Norden i et stærkt Europa.

Det nordiske samarbejde ønsker at styrke nordiske og regionale interesser og værdier i en global omverden. Fælles værdier landene imellem er med til at styrke Nordens position som en af verdens mest innovative og konkurrencedygtige regioner.

\section{Nordisk Ministerråd}

Nordens Hus

Ved Stranden 18

1061 København K

www.norden.org

Download nordiske publikationer: www.norden.org/nordpub 


\section{Planer og budget 2018 - sammenfatning}

\section{Indholdsfortegnelse}

Planer og budsjett 2018

Budgettets totalramme og budgettet fordelt på budgetsektorer

Huvudlinjer i budgeten 2018

Nordiska ministerrådets politiska prioriteringar

Drøftinger med Nordisk råd om Nordisk ministerråds budsjett 2018

Budgettets indtægter og landenes indbetalinger

Landenes prognosticerede indbetalinger i national valuta

Udviklingen i Nordisk Ministerråds budget

Budgettets udvikling i perioden 2006-2018

Udviklingen i udisponerede midler 2013-2016

Likviditetens udvikling

Oversigt over Nordisk Ministerråds budget på budgetpostniveau

Bilag 1: De nordiske institutioners bevillinger i national valuta 


\section{Planer og budsjett 2018}

"Nordens tid er nå" er overskriften for neste fase av reformarbeidet "Nytt Norden", som de nordiske samarbeidsministrene vedtok å iverksette i september 2016. Det nordiske samarbeidet har siden 2014 vært preget av et omfattende reformarbeid. Målet er å sikre et dynamisk og veldrevet nordisk samarbeid som er relevant for de nordiske regjeringene, næringsliv og sivilsamfunn. Med de gjennomførte reformtiltakene begynner vi nå å høste fruktene i form av et mer politisk fokusert nordisk samarbeid, som i høyere grad avspeiler de aktuelle problemstillingene landene står overfor. Politisering, effektivisering og internasjonalisering er sentrale stikkord for reformen.

Det stiller nye krav til det nordiske budsjettet. Budsjettet skal brukes mer dynamisk og fleksibelt for å imøtekomme nye behov og ønsker i landene. På denne bakgrunnen endres fordelingen av budsjettet for å tilgodese grønn omstilling og samarbeidet på helse- og sosialområdet i Norden. Konkret betyder det at forskning på energiområdet styrkes ved å forhøye bevilgningen til institusjonen Nordisk Energiforskning. Videre økes NordGens bevilgning med henblikk på å framtidssikre oppbevaring og preservering av grunnleggende data om planter/frø. Endelig styrkes folkehelsesamarbeidet, i tråd med oppfølgingen av den strategiske gjennomlysningen av helsesektoren fra 2015.

I tillegg legges det opp til at den brede tverrgående satsingen på samarbeidet om integrering av flyktninger og innvandrere som ble initiert i 2016, fortsetter med samme intensitet i 2018 , noe som reflekterer et fortsatt ønske om at nordisk samarbeid skal svare på aktuelle utfordringer i de nordiske landene. Det gjelder også nettverket Nordic Safe Cities.

Det nordiske samarbeidet om digitalisering blir også sentralt det kommende året, med et forsterket og fleksibelt ad hoc-samarbeid på ministernivå. 
Som region representerer de nordiske landene ikke bare den 12. største økonomien i verden. Vi står også for løsninger og erfaringer innenfor f.eks. likestilling, grønn omstilling og velferd som etterspørres både i Europa og i resten av verden. Det er bakgrunnen for det nordiske statsministerinitiativet "Nordiske løsninger på globale utfordringer" og den felles nordiske strategien for profilering og posisjonering av Norden som fortsettes i 2018. Det er også bakgrunnen for samarbeidet om internasjonale spørsmål og EU-saker av felles interesse, som prioriteres $i$ alle ministerråd. Det samme gjelder den felles nordiske oppfølgingen av de globale klimaforhandlingene.

Nordiske løsninger kan dessuten være et effektivt verktøy for å oppnå FNs bærekraftmål innen 2030. Nordisk samarbeid støtter derfor opp om arbeidet som gjøres i landene på dette feltet.

De strategiske gjennomlysningene har vist seg å være et svært effektivt verktøy for å identifisere potensialet for framtidig nordisk samarbeid innenfor et spesifikt samarbeidsområde. Derfor settes det også i 2018 av midler til å følge opp gjennomlysningene på energi-, miljø-, arbeidslivs- og sosialområdet, samt midler til å gjennomføre en ny gjennomlysning.

Det har vært en god og konstruktiv dialog gjennom hele budsjettprosessen med Nordisk råd. I den årlige drøftelsen med Nordisk råd høsten 2017 om Nordisk ministerråds budsjett ble det oppnådd enighet om et kompromiss. Dette budsjettkompromisset er i sin helhet tatt inn i budsjettboken.

Den totale rammen for budsjettet er på nivå med 2017. Ordningen med et prioriteringsbudsjett som også omfatter formannskapslandets prosjekter, videreføres i 2018.

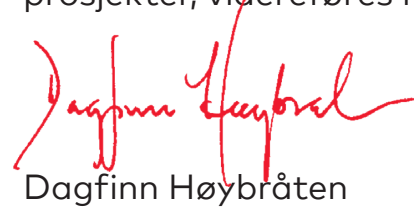

Generalsekretær i

Nordisk ministerråd 


\section{Budgettets totalramme og budgettet fordelt på budgetsektorer}

Den totale udgiftsramme for 2018 for Nordisk Ministerråd er i alt 935.091 TDKK (2017-niveau), som er vændret realramme i forhold til budget 2017 .

Til budgetrammen for 2018 (i 2017-niveau) lægges effekten af pris- og valutaomregningen med de prisomregningsfaktorer og valutakurser, som vises i bilag 2, og det giver den totale udgiftsramme for Nordisk Ministerråd for 2018.

Rammen kan specificeres således:

\section{Sammensætningen af den samlede ramme TDKK \\ Vedtaget budget $2018 \mathrm{i}$ 2017-niveau 935.091 \\ Prisomregningseffekt til 2018-niveau \\ Valutaomregningseffekt \\ Total i 2018 priser 950.862}

Effekten af prisopregningen i budget 2018 indebærer en inflationskompensation på 13.922 TDKK svarende til en gennemsnitlig prisopregningsprocent på 1,5\%. Effekten af valutaomregningen til DKK af institutionernes bevillinger i national valuta indebærer en forøgelse af budgettet på 1.849 TDKK. Det skal dog understreges, at det ikke har nogen realvirkning på budgettets størrelse (og landenes indbetalinger) eller på størrelsen af institutionernes bevillinger. Valutakurserne benyttes alene til at omregne institutionernes bevillinger, som udbetales i domicillandets valuta, til DKK.

På næste side ses fordeling af udgiftsrammen på budgetsektorer for 2018. 


\section{Sammenstilling af budget 2018 og 2017 (årets priser)}

\begin{tabular}{|c|c|c|c|c|c|}
\hline & \multirow{2}{*}{$\begin{array}{c}\text { Budget } \\
2018\end{array}$} & \multirow{2}{*}{$\begin{array}{l}\text { Budget } \\
2017\end{array}$} & \multicolumn{2}{|c|}{ Difference } \\
\hline & & & & $+/-$ & $\%$ \\
\hline \multirow[t]{6}{*}{1.} & MR Samarbejdsministrene & 262.059 & 258.184 & 3.875 & $1,5 \%$ \\
\hline & a. Prioriteringsbudgettet & 88.351 & 91.842 & -3.491 & $-3,8 \%$ \\
\hline & b. Internationalt samarbejde & 60.657 & 55.261 & 5.396 & $9,8 \%$ \\
\hline & i. Heraf kontorerne* & 16.015 & 15.778 & 237 & $1,5 \%$ \\
\hline & $\begin{array}{l}\text { c. Nordisk Ministerråds } \\
\text { fællesaktiviteter og } \\
\text { Sekretariatet }\end{array}$ & 113.051 & 111.081 & 1.970 & $1,8 \%$ \\
\hline & $\begin{array}{l}\text { i. Heraf sekretariatet } \\
\text { (NMRS) }\end{array}$ & 80.433 & 79.244 & 1.189 & $1,5 \%$ \\
\hline \multirow[t]{6}{*}{2.} & MR Uddannelse og Forskning & 221.338 & 221.541 & -203 & $-0,1 \%$ \\
\hline & $\begin{array}{l}\text { a. Generelle forsknings- og } \\
\text { uddannelsesinitiativer }\end{array}$ & 3.427 & 3.376 & 51 & $1,5 \%$ \\
\hline & b. Politikudvikling mv. & 15.954 & 15.718 & 236 & $1,5 \%$ \\
\hline & $\begin{array}{l}\text { c. Mobilitets- og netværks- } \\
\text { programmer }\end{array}$ & 81.510 & 80.306 & 1.204 & $1,5 \%$ \\
\hline & d. NordForsk (institution) & 100.224 & 99.442 & 782 & $0,8 \%$ \\
\hline & e. Forskning i øvrigt & 20.223 & 22.699 & -2.476 & $-10,9 \%$ \\
\hline \multirow[t]{2}{*}{3.} & MR Social- og Helsepolitik & 43.290 & 39.363 & 3.927 & $10,0 \%$ \\
\hline & $\begin{array}{l}\text { i. Heraf Nordens Välfärds- } \\
\text { center (institution) }\end{array}$ & 19.661 & 20.083 & -422 & $-2,1 \%$ \\
\hline \multirow[t]{7}{*}{4.} & MR Kultur & 176.797 & 174.413 & 2.384 & $1,4 \%$ \\
\hline & a. Generelle kultursatsninger & 51.637 & 51.496 & 141 & $0,3 \%$ \\
\hline & b. Børn og Unge & 6.344 & 6.250 & 94 & $1,5 \%$ \\
\hline & c. Film og Media & 32.222 & 31.846 & 376 & $1,2 \%$ \\
\hline & d. Kunstområdet & 31.760 & 31.820 & -60 & $-0,2 \%$ \\
\hline & $\begin{array}{l}\text { e. Nordiske Kulturhuse } \\
\text { (institutioner) }\end{array}$ & 48.144 & 46.010 & 2.134 & $4,6 \%$ \\
\hline & f. Andre kultursatsninger & 6.690 & 6.991 & -301 & $-4,3 \%$ \\
\hline \multirow[t]{5}{*}{5.} & $\begin{array}{l}\text { MR Fiskeri og Havbrug, } \\
\text { Jordbrug, Levnedsmidler } \\
\text { og Skovbrug }\end{array}$ & 42.164 & 40.219 & 1.945 & $4,8 \%$ \\
\hline & a. Fiskeri & 6.512 & 6.416 & 96 & $1,5 \%$ \\
\hline & b. Jord- og Skovbrug & 28.823 & 27.074 & 1.749 & $6,5 \%$ \\
\hline & $\begin{array}{l}\text { i. Heraf NordGen } \\
\text { (institution) }\end{array}$ & 21.409 & 19.769 & 1.640 & $8,3 \%$ \\
\hline & c. Levnedsmidler & 6.829 & 6.729 & 100 & $1,5 \%$ \\
\hline
\end{tabular}




\section{Sammenstilling af budget 2018 og 2017 (årets priser)}

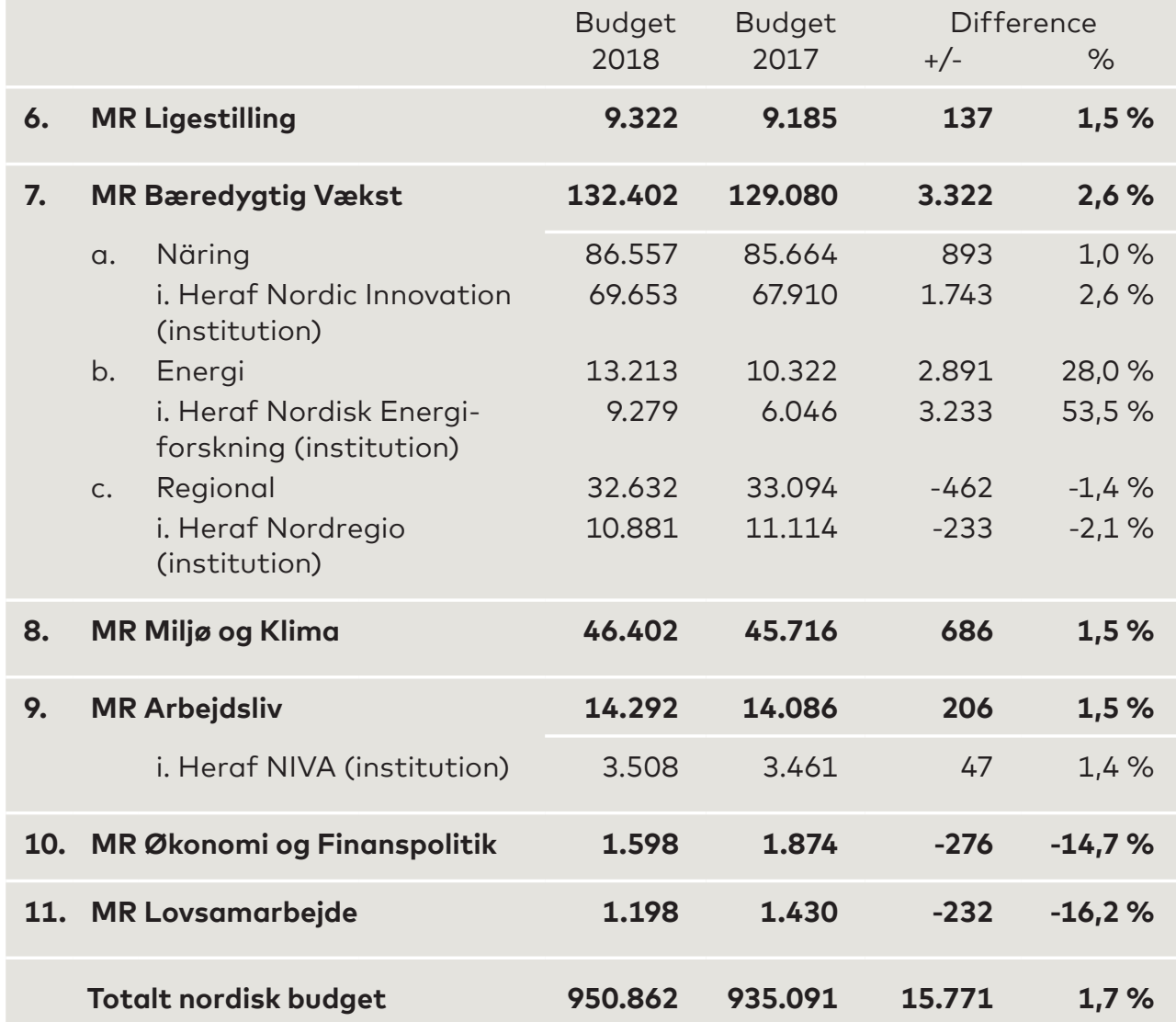

*Ministerrådets kontorer i Estland, Letland, Litauen og Nordvestrusland

Rammerne fordelt på budgetpostniveau ses i tabellerne fra side 23. 


\section{Huvudlinjer i budgeten 2018}

Nordiska ministerrådet är ett formellt samarbete mellan de nordiska regeringarna. Ministerrådets arbete regleras av Helsingforsavtalet från 1971.

Ordförandeskapet för Nordiska ministerrådet roterar mellan länderna på årlig basis. Sverige tar 2018 över ordförandeskapet efter Norge.

Det är de nordiska samarbetsministrarna (MR-SAM), som har det övergripande ansvaret för att koordinera arbetet i Nordiska ministerrådet. Därtill utförs samarbetet i tio fackministerråd.

Den nordiska budgetens totala ram är i år oförändrad i förhållande till 2017. Det har dock skett en omfördelning av den totala ramen mellan sektorerna i syfte att stärka nordiskt samarbete om social- och hälsofrågor samt grön omställning. Det innebär att MR-S, MR-FJLS och MR-Tillväxts ram har ökats medan de traditionellt största sektorerna Utbildning och Forskning samt Kultur har minskat med ca 2 respektive 1 procent. Vidare har MR-Finans och MR-Lags budget minskat med 0,3 miljoner DKK respektive 0,25 miljoner DKK.

Dessutom har samarbetsministrarna omprioriterat inom ramen för sin egen budget 2018. Konsekvensen är att prioriteringsbudgeten, som 2017 ökades kraftigt, i år minskas något till fördel för den internationella budgeten och implementeringen av Rysslandsprogrammet. För mer information se avsnittet om Nordiska ministerrådets politiska prioriteringar.

Vidare fortsätter ordförandeskapsprojekten från Finland (2016) och Norge (2017) under 2018. Dessutom lanserar Sverige sina prioriterade ordförandeskapsprojekt.

Budgeten har utarbetats mot bakgrund av fackministerrådens 
bidrag till prioriteringar och presenterades som generalsekreterarens budgetförslag i juni 2017. Förslaget har därefter varit på remiss i de nordiska länderna. Samarbetsministrarna fattade i september
2017 beslut om budgetförslaget. Den slutgiltiga budgeten för Nordiska ministerrådet 2018 antogs av de nordiska samarbetsministrarna i november 2017 efter diskussioner med Nordiska rådet. 


\section{Nordiska ministerrådets politiska prioriteringar}

Arbetet med att säkerställa att det nordiska samarbetet förblir ett dynamiskt och relevant redskap när det kommer till att hantera gemensamma politiska utmaningar i Norden fortsätter 2018.

Ett verktyg som kan bidra till ökad relevans i det nordiska regeringssamarbetet är de nordiska samarbetsministrarnas prioriteringsbudget. Denna budget, vars syfte är att möjliggöra och facilitera igångsättandet av nya och större tvärgående projekt/program samt ländernas ordförandeskapssatsningar, har existerat sedan 2013.

2018 används prioriteringsbudgeten bland annat för att fortsätta finansiera statsministerinitiativet om nordiska lösningar på globala samhällsutmaningar samt det breda nordiska samarbetsprogrammet om integration av flyktingar och invandrare.

Därutöver prioriteras tvärgående insatser om nordiskt statistiksamarbete, miljö och klimat (uppföljning på de globala klimatkonferenserna), digitalisering samt bekämpning av social marginalisering, extremism och religiös diskriminering genom samarbete om demokrati, inkludering och säkerhet.

I linje med Nytt Norden-reformen läggs det också stort fokus vid uppföljningen av de strategiska genomlysningarna av det nordiska arbetsmarknads-, miljö-, energisamt socialsamarbetet $\mathrm{i}$ budgeten 2018. Uppföljningen av hälsogenomlysningen säkras via den ökade budgeten till social- och hälsosektorn. Det reserveras också medel för att igångsätta en ny genomlysning under året.

Nordiska ministerrådet prioriterar också fortsatt människors och företags gränsöverskridande aktiviteter i Norden högt via Gränshinderrådet och dess arbete.

Fokus på internationella frågor och EU-saker har ökat i Nordiska ministerrådet som en följd av reformen Nytt Norden. Idag har alla minister- 
råd internationella och EU-frågor på dagordningen, vilket både resulterar i gemensamma deklarationer och aktiviteter riktade mot EU och andra internationella aktörer. Det sker också koordinering och samarbete mellan länderna i nationella lagstiftningsprocesser samt implementering av EU-lagstiftning.

Nordiska ministerrådet har vidare konstaterat att intresset för Norden är ökande runt om i världen. Med anledning av det har ministerrådet godkänt en gemensam strategi för profilering och positionering av Norden som en attraktiv region både i förhållande till turism, näringsliv och internationellt kapital. Parallellt med detta fortsätter också statsministerinitiativet om nordiska lösningar på globala samhällsutmaningar. Initiativet, som syftar till att öka kunskapen och främja gemensamma nordiska initiativ som kan tillmötesgå den globala efterfrågan efter innovativa samhällslösningar, ska ses i samband med det nya nordiska samarbetsprogrammet om Agenda 2030 som ska bidra till de nordiska ländernas uppföljning av Agenda 2030.

Avslutningsvis bör nämnas att Nordiska ministerrådet prioriterar barn- och ungdom, jämställdhet och hållbar utveckling högt och därför integreras dessa tvärgående perspektiv i hela Nordiska ministerrådets verksamhet. 


\section{Drøftinger med Nordisk råd om Nordisk ministerråds budsjett 2018}

Høsten 2017 ble det gjennomført politiske forhandlinger mellom Nordisk råd og Nordisk ministerråd om ministerrådets budsjettforslag som resulterte i følgende endringer/presiseringer i budsjettet for 2018:

Att ensamkommande flyktingbarns hälsa - specifikt psykisk hälsa inkluderas i budgeten.

Att avsätta upp till 500000 DKK till en bakgrundsutredning om nordisk insats i globalt freds- och försoningsarbete, inklusive bidrag till att öka kvinnors deltagande och inflytande i processer knutna till fred och säkerhet.
Att avsätta medel för en kartläggning av hur nordiska public service kanalerna kan bli tillgängliga i hela Norden, härunder titta på geoblockering.

Att avsätta medel till en sammanfattande utredning om nordiskt arbete om sjöfartsrisker och miljösäkerhet i arktisk sjöfart.

Att Nordiska rådet ber om att få till behandling ett skyndsamt MRförslag om framtidig långsiktig finansiering av de fem samarbetsorganen under utbildningssektorn. Innan det är färdigbehandlat önskar rådet dock vidhålla att finansiering av Samiska institutet (NSI) ligger på samma nivå som 2017. 


\section{Budgettets indtægter og landenes indbetalinger}

Nordisk Ministerråds budget finansie- indbetalinger sker $\mathrm{i}$ henhold til en res hovedsageligt af direkte bidrag fra landene. Som udgangspunkt indbetaler landene et beløb svarende til aktivitetsrammen fratrukket afgift på løn, nettorenteindtægter og øvrige indtægter, som det fremgår af nedenstående tabel. Landenes

\begin{abstract}
særskilt fordelingsnøgle, som er beregnet på basis af det respektive lands andel af den samlede bruttonationalindtægt i faktorpriser i Norden for de to seneste kendte år, som i budgettet for 2018 er 2014 og 2015.
\end{abstract}

\begin{tabular}{|c|c|c|c|c|c|c|c|c|}
\hline $\begin{array}{l}\text { Indtægter } \\
\text { TDKK } \\
\text { (årets } \\
\text { priser) }\end{array}$ & $\begin{array}{l}\text { Budget } \\
2015\end{array}$ & $\begin{array}{l}\text { Ford. } \\
\text { nøgle } \\
2015\end{array}$ & $\begin{array}{c}\text { Budget } \\
2016\end{array}$ & $\begin{array}{c}\text { Ford. } \\
\text { nøgle } \\
2016\end{array}$ & $\begin{array}{c}\text { Budget } \\
2017\end{array}$ & $\begin{array}{l}\text { Ford. } \\
\text { nøgle } \\
2017\end{array}$ & $\begin{array}{c}\text { Budget } \\
2018\end{array}$ & $\begin{array}{l}\text { Ford. } \\
\text { nøgle } \\
2018\end{array}$ \\
\hline $\begin{array}{l}\text { Afgift } \\
\text { på løn }\end{array}$ & 13.000 & & 12.500 & & 13.500 & & 13.500 & \\
\hline $\begin{array}{l}\varnothing v r i g e \\
\text { indtæg- } \\
\text { ter (f.eks. } \\
\text { renter) }\end{array}$ & 600 & & 400 & & 0 & & 0 & \\
\hline $\begin{array}{l}\text { Landenes } \\
\text { bidrag }\end{array}$ & 922.510 & & 914.646 & & 921.591 & & 937.362 & \\
\hline - Danmark & 184.502 & $20,0 \%$ & 177.441 & $19,4 \%$ & 184.638 & $20,2 \%$ & 197.783 & $21,1 \%$ \\
\hline - Finland & 142.989 & $15,5 \%$ & 143.599 & $15,7 \%$ & 145.611 & $15,8 \%$ & 150.915 & $16,1 \%$ \\
\hline - Island & 6.458 & $0,7 \%$ & 7.317 & $0,8 \%$ & 8.294 & $0,9 \%$ & 9.374 & $1,0 \%$ \\
\hline - Norge & 290.591 & $31,5 \%$ & 295.431 & $32,3 \%$ & 292.144 & $31,7 \%$ & 283.083 & $30,2 \%$ \\
\hline - Sverige & 297.971 & $32,3 \%$ & 290.857 & $31,8 \%$ & 289.380 & $31,4 \%$ & 296.206 & $31,6 \%$ \\
\hline Sum: & 936.110 & $100 \%$ & 927.546 & $100 \%$ & 935.091 & $100 \%$ & 950.862 & $100 \%$ \\
\hline
\end{tabular}




\section{Landenes prognosticerede indbetalinger i national valuta}

Det er besluttet i Overenskomsten om adgang til videregående uddannelse, at konsekvenserne af betalingsordningen for de nordiske lande skal reguleres over Ministerrådets budget. Beslutningen påvirker derved landenes bidrag til det nordiske budget. Betalingsordningen gælder Danmark, Finland, Norge og Sverige. Island, Grønland, Færøerne og Åland står uden for betalingsordningen. Der tages hensyn til landenes gensidige betalinger i landenes bidrag, og aftalen påvirker alene den interne fordeling af bidragene mellem landene (Danmark, Finland, Norge og Sverige). Det er i 2015 besluttet at forlænge overenskomsten til udgangen af 2018.
Af overenskomsten fremgår det, at der skal ske betaling for $75 \%$ af det antal studerende, som modtager studiestøtte fra det land, hvor den studerende er bosat efter gældende regler i det land, og som er indskrevet på en højere uddannelse i et andet land, som falder ind under Artikel $1 \mathrm{i}$ overenskomsten.

Forskningsuddannelser samt studerende på uspecificeret højere uddannelse medregnes ikke i beregningsgrundlaget. Den årlige erstatning pr. studerende er 30.740 DKK i 2018.

Ministerrådet modtager statistik fra de nordiske studiestøttemyndigheder, som ligger til grund for

\section{Betalingsordning, højere uddannelse TDKK}

\begin{tabular}{lrrrr|} 
& Budget 2015 & Budget 2016 & Budget 2017 & Budget 2018 \\
\hline Danmark & -85.457 & -83.278 & -78.963 & -77.718 \\
Finland & 24.387 & 29.137 & 33.861 & 43.689 \\
Island & 0 & 0 & 0 & 0 \\
Norge & 59.456 & 57.479 & 51.225 & 50.375 \\
Sverige & 1.614 & -3.338 & -6.123 & -16.346 \\
\hline Sum: & 0 & 0 & 0 & 0
\end{tabular}


beregningen af antal studerende mellem de nordiske lande, der indgår i ordningen.

Nedenfor vises landenes indbetalinger til Nordisk Ministerråd i tusinder

\begin{tabular}{l}
$\begin{array}{l}\text { Budget 2018 - Landenes } \\
\text { prognosticerede bidrag i } \\
\text { national valuta }\end{array}$ \\
\hline Danmark \\
Finland \\
Island \\
Norge \\
Sverige \\
\hline
\end{tabular}

er til Nordisk Ministerråditusinder af det enkelte lands valuta med udgangspunkt i de af samarbejdsministrene godkendte budgetvalutakurser i bilag 2. Beløbene inkluderer betalingsordningen. 


\section{Udviklingen i Nordisk Ministerråds budget}

En måde at undersøge udviklingen i Nordisk Ministerråds budget på over langt sigt er at sammenligne budgettet med de nordiske landes samlede bruttonationalprodukt (BNP). Det nordiske BNP er summen af BNP i Danmark, Finland, Island, Norge og Sverige. Nedenstående graf viser budgettets andel af det nordiske BNP siden 1995, og det viser, at Ministerrådets budget sammenlignet med BNP falder i perioden.
Sammenligningen er foretaget for perioden 1995-2016, og år 1995 er sat til indeks 100. Forøgelsen af budgettets relative andel i 2009 skyldes primært den økonomiske krise i 2008. Alle landenes BNP faldt i 2009 i forhold til 2008, og som følge heraf udgør Ministerrådets budget det år en større andel af det nordiske BNP.

Det ses af søjlediagrammet, at budgettets andel af BNP udgjorde indeks 55 i 2016.

\section{NMR-budget som andel af BNP-norden}

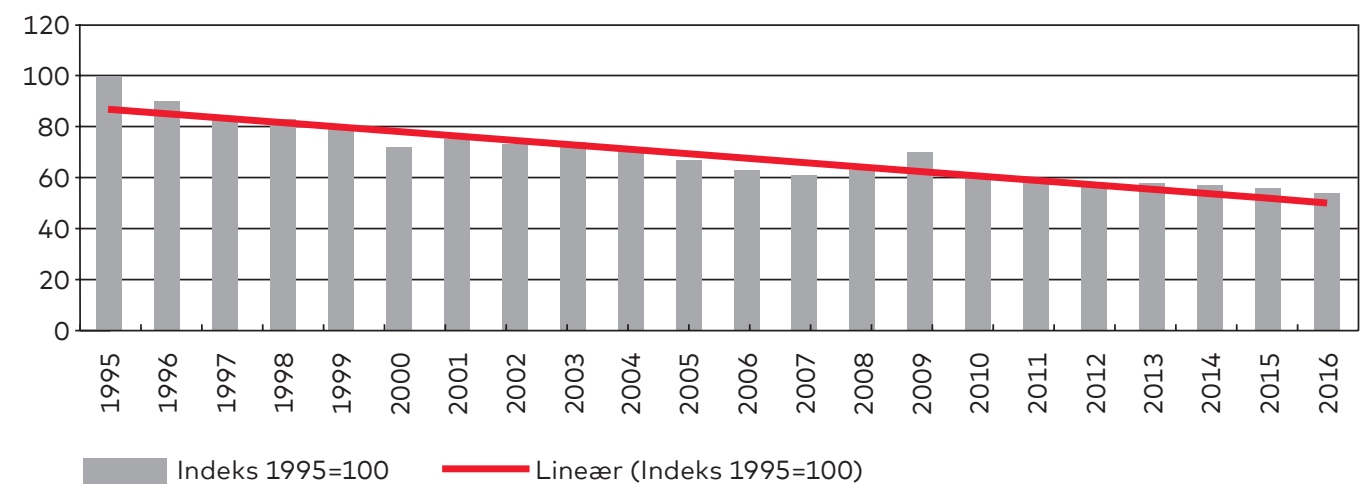




\section{Budgettets udvikling i perioden 2006-2018}

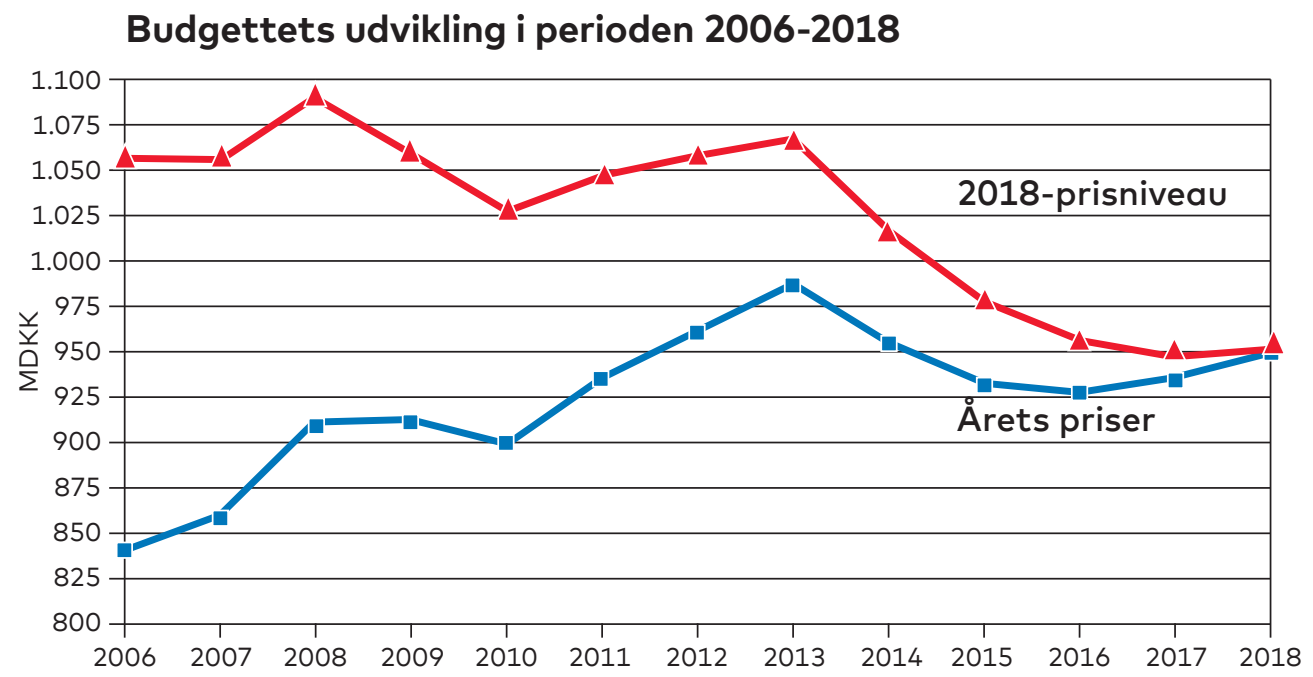

MR-SAM har for 2018 vedtaget en ramme, der er på niveau med budget 2017.

Stigningen fra 2007 til 2008 skal ses på baggrund af beslutningen i forbindelse med budget 2008 om at finansiere en del af globaliseringssatsninger på 60 MDKK i 2008, som statsministrene lancerede $\mathrm{i}$ Punkaharju i Finland i juni 2007 med en forøgelse af aktivitetsrammen på 35 MDKK.

Når budgettet i faste priser i 2010 falder i forhold til 2009, og fortsat i 2011 ligger under niveauet for 2009, skyldes det de udsving, der har været i valutakurserne. I dette tilfælde skyldes det konkret det store fald $\mathrm{i}$ norske og svenske kroners værdi fra sidste halvdel af 2008 til midten af 
2009 i forhold til danske kroner.

Stigningen fra 2011 til 2012 og

fortsat til 2013 skyldes på samme

måde stigningen i norske og svenske

kroner i forhold til danske kroner.

Det relativt store fald i faste priser

i 2014 til 2015 og fortsat til 2016 skyldes, foruden nedskæringer i budgettet 2014-2016, faldet i norske og svenske kroners værdi i forhold til danske kroner. Fortsat fald i norske og svenske kroner forklarer også nedgangen i 2016 og 2017. 


\section{Udviklingen i udisponerede midler 2013-2016}

Udisponerede midler er defineret som midler, hvor der ikke er foretaget en beslutning om anvendelse til et bestemt formål. Udisponerede midler kan alene forekomme under budgetposter med projektmidler og programlignende aktiviteter, idet Ministerrådet på institutioner og organisationsbidrag udbetaler alle midler til eksterne parter, som har dispositionsretten over midlerne, og derfor er disse midler i Ministerrådets budget altid pr. definition
$100 \%$ disponeret. Projektmidler og programlignende aktiviteter udgjorde totalt ca. $57 \%$ af Ministerrådets budget i 2016 .

I forbindelse med en tidligere modernisering af budgettet og vedtagelse af Generalsekretærens forslagskatalog i 2007 besluttede MR-SAM at indføre en 20-procentsregel kombineret med et minimumsbeløb på 200.000 DKK, som betød, at højst 20 \% af årets budget på en budget-

\section{Udisponerede midler ultimo 2013-2016}

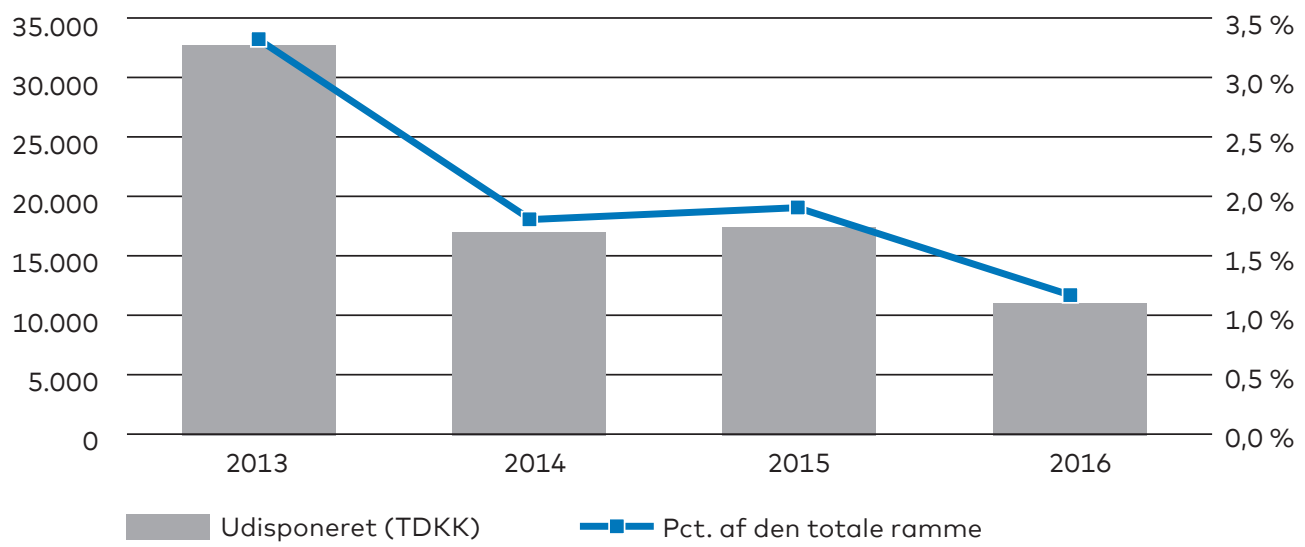




\section{Udisponerede midler ultimo 2013-2016}

\begin{tabular}{|c|c|c|c|c|c|c|c|c|c|}
\hline Sektor (TDKK) & 2013 & $\begin{array}{l}\% \text { af } \\
\text { sekt. } \\
\text { stør- } \\
\text { relse }\end{array}$ & 2014 & $\begin{array}{l}\% \text { af } \\
\text { sekt. } \\
\text { stør- } \\
\text { relse }\end{array}$ & 2015 & $\begin{array}{l}\% \text { af } \\
\text { sekt. } \\
\text { stør- } \\
\text { relse }\end{array}$ & 2016 & $\begin{array}{l}\% \text { af } \\
\text { sekt. } \\
\text { stør- } \\
\text { relse }\end{array}$ & $\begin{array}{c}\text { Beskå- } \\
\text { ret jf. } \\
15 \% \\
\text { regl. }\end{array}$ \\
\hline $\begin{array}{l}\text { Prioriterings- } \\
\text { budgettet }\end{array}$ & 3.242 & $4 \%$ & 3.939 & $5 \%$ & 3.841 & $5 \%$ & 2.372 & $3,1 \%$ & 1.505 \\
\hline $\begin{array}{l}\text { Internationalt } \\
\text { samarbejde }\end{array}$ & 8.474 & $9 \%$ & 2.618 & $3 \%$ & 6.090 & $8 \%$ & 653 & $0,9 \%$ & 4.872 \\
\hline $\begin{array}{l}\text { Uddannelse og } \\
\text { forskning }\end{array}$ & 11.064 & $5 \%$ & 1.970 & $1 \%$ & 1.049 & $0 \%$ & 1.422 & $0,6 \%$ & 342 \\
\hline $\begin{array}{l}\text { Social-og } \\
\text { Helsepolitik }\end{array}$ & 897 & $2 \%$ & 865 & $2 \%$ & 268 & $1 \%$ & 185 & $0,5 \%$ & 0 \\
\hline FJLS & 856 & $2 \%$ & 1.714 & $4 \%$ & 122 & $0 \%$ & 367 & $0,9 \%$ & 0 \\
\hline Kulturpolitik & 788 & $0 \%$ & 593 & $0 \%$ & 1.473 & $1 \%$ & 2.453 & $1,4 \%$ & 0 \\
\hline Ligestilling & 1.045 & $11 \%$ & 28 & $0 \%$ & 142 & $2 \%$ & 90 & $1,0 \%$ & 0 \\
\hline Bæredygtig vækst & 781 & $1 \%$ & 2.347 & $2 \%$ & 1.541 & $1 \%$ & 1.033 & $0,8 \%$ & 0 \\
\hline Miljø og klima & 716 & $2 \%$ & 629 & $1 \%$ & 1.111 & $3 \%$ & 699 & $1,6 \%$ & 0 \\
\hline Arbejdsliv & 1.103 & $8 \%$ & 883 & $6 \%$ & 396 & $3 \%$ & 150 & $1,1 \%$ & 0 \\
\hline $\begin{array}{l}\varnothing \text { konomi og } \\
\text { Finanspolitik }\end{array}$ & 54 & $3 \%$ & 67 & $4 \%$ & 191 & $11 \%$ & 41 & $2,3 \%$ & 0 \\
\hline Lovsamarbejde & 188 & $13 \%$ & 209 & $15 \%$ & 207 & $15 \%$ & 211 & $15,0 \%$ & 28 \\
\hline$\varnothing$ vrig virksomhed & 3.564 & $3 \%$ & 1.342 & $1 \%$ & 1.190 & $1 \%$ & 1.506 & $1,4 \%$ & 591 \\
\hline SUM & 32.772 & $\%$ & 17.204 & $1,8 \%$ & 17.621 & $9 \%$ & 11.182 & $1,2 \%$ & 7.338 \\
\hline
\end{tabular}

post kunne videreføres til næste år; dog kunne man altid videreføre 200.000 DKK. Denne regel er med moderniseringen af budgettet i 2014 ændret til en 15-procentsregel med et minimumsbeløb på 150.000 DKK.

Samarbejdsministrene besluttede i maj måned 2009, at fra og med virksomhedsår 2009 skal midler, som falder for 15-procentsreglen, tilbageføres til landene. Beslutningen er taget på baggrund af, at budgetrammen i 2008 blev udvidet med et engangsløft på 35 MDKK til finansiering af globaliseringsinitiativerne.

På side 20 er grafisk vist de udisponerede midler for perioden 2013-2016 samt en oversigt over fordelingen af de udisponerede midler fordelt på ministerråd i TDKK og i procent af sektorens samlede ramme.

1 Minimumsgrænsen er indført af hensyn til de små projektbudgetposter, som en procentordning alene vil ramme uforholdsmæssigt hårdt. 


\section{Likviditetens udvikling}

Nedenstående graf viser to serier. Den blå serie viser den samlede likviditets højeste punkt hvert kvartal, og den røde serie viser den laveste. Likviditetsbeholdingen indeholder Ministerrådets totale likviditet, hvor likviditeten i anden valuta end dansk er omregnet til danske kroner.

Fra og med budgetåret 2008 er landene begyndt at indbetale 4 gange årligt mod tidligere 2 gange, hvilket indebærer et ændret mønster i
Ministerrådets likviditetsbeholdning. Fra og med midten af året 2014 er landene begyndt at indbetale 8 gange om året, hvor 4 indbetalinger er $\mathrm{i}$ DKK, og 4 er i landenes valuta.

MR-SAM besluttede i november 2010 at forskyde landenes indbetalinger med to måneder. Effekten heraf er, at Ministerrådets samlede likviditet er reduceret betydeligt allerede i 2011 og på visse tidspunkter derefter er tæt på nul.

\section{TDKK Likviditetens udvikling}

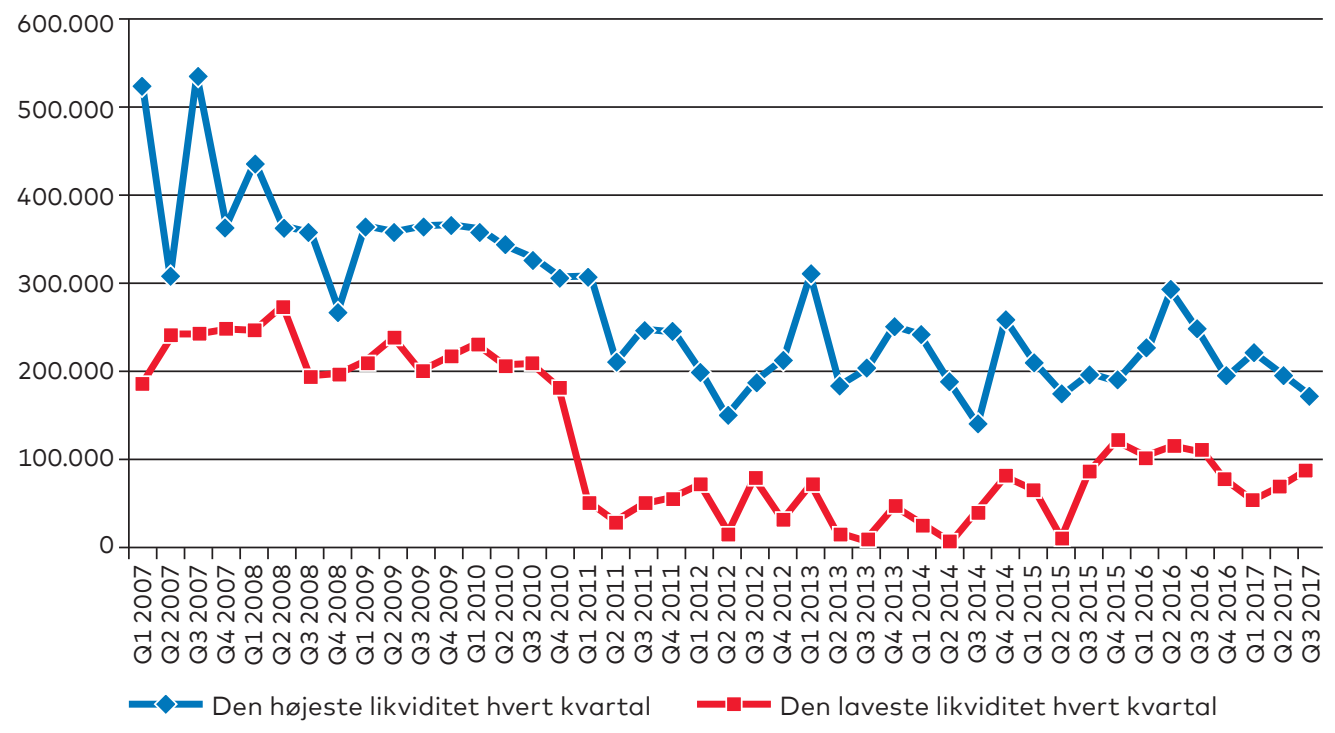




\section{Oversigt over Nordisk Ministerråds budget på budgetpostniveau}

TDKK

$\begin{array}{cc}\text { Budget } & \text { Budget } \\ 2018 & 2017\end{array}$

Prioriteringsbudgettet (MR-SAM)

$88.351 \quad 91.842$

Formandskabspuljen, Sverige

15.225

0

1-8025 Vård på distans (telemedicin) och

4.060

0

e-recept över landsgränser

1-8026 Främjande av nordiska hållbarhetslösningar

$4.060 \quad 0$

1-8027 Hållbara nordiska städer med fokus på klimatsmart mobilitet

1-8028 Ungas sociala inkludering och delaktighet i utsatta områden

Formandskabspuljen, Norge

15.226

15.270

1-8019 Grønn omstilling og konkurransekraft

3.045

2.749 i nordiske byregioner

1-8020 Blå og grønn bioøkonomi

3.756

3.563

1-8021 Helse

2.132

2.341

1-8022 Integration

5.075

5.294

1-8023 Styrket samarbeid mellom de utenrikspolitiske insti-

1.015

509 tuttene

1-8024 Nordisk energisamarbeid

203

814

Formandskabspuljen, Finland

15.225

15.273

1-8012 Statistisk utredning över nordisk rörlighet och

3.806

3.818

förmåner över gränserna

1-8013 Forskarutbyte mellan de nordiska utrikespolitiska instituten

1-8014 Miljömärkning Svanen, cirkulär ekonomi och miljöavtryck

1-8015 Ett innovativt och öppet Norden med välmående människor 2020

1-8016 Nordisk vägkarta för Blå Bioekonomi

761

764

761

764

2.284

2.291

1-8017 Socio-ekonomisk nytta av arktiska ytvatten

2.284

2.291

i Norden

1.523

1.527

1-8018 The Rising North

3.806

3.818

Fortsættes næste side 


\begin{tabular}{|c|c|c|c|}
\hline TDKK & & $\begin{array}{l}\text { Budget } \\
2018\end{array}$ & $\begin{array}{l}\text { Budget } \\
2017\end{array}$ \\
\hline & Formandskabspuljen, Danmark & 0 & 14.643 \\
\hline 1-8008 & Vækst & 0 & 3.954 \\
\hline $1-8009$ & Velfærd & 0 & 4.072 \\
\hline $1-8010$ & Værdier & 0 & 4.072 \\
\hline $1-8011$ & Det blå Arktis & 0 & 2.545 \\
\hline & Prioriteringspuljen & 42.675 & 46.656 \\
\hline $1-8410$ & Politiska prioriteringar & 5.583 & 7.126 \\
\hline $1-8411$ & Politiske initiativer & 8.722 & 8.593 \\
\hline $1-8412$ & Till disposition för MR-SAM & 2.070 & 5.283 \\
\hline $1-8420$ & Profilering og positionering & 10.333 & 10.180 \\
\hline $1-8510$ & Nye tværgående initiativer & 4.517 & 5.294 \\
\hline $1-8520$ & $\begin{array}{l}\text { Nordiska lösningar på globala } \\
\text { samhällsutmaningar }\end{array}$ & 10.333 & 10.180 \\
\hline $1-8530$ & MR-Digital & 1.117 & 0 \\
\hline TDKK & & $\begin{array}{l}\text { Budget } \\
2018\end{array}$ & $\begin{array}{l}\text { Budget } \\
2017\end{array}$ \\
\hline & Fællesaktiviteter og Sekretariatet (MR-SAM) & 113.051 & 111.081 \\
\hline & Nordisk Ministerråds fællesaktiviteter & 32.618 & 31.837 \\
\hline $1-0410$ & Föreningarna Nordens Förbund & 3.391 & 3.341 \\
\hline $1-0425$ & Bidrag til Grönland & 761 & 750 \\
\hline $1-0435$ & Generalsekreterarens disponeringsreserv & 433 & 427 \\
\hline $1-0460$ & Hållbar utveckling (tidigare Hållbart Norden) & 3.179 & 3.132 \\
\hline $1-1011$ & Informationsaktiviteter & 5.730 & 5.345 \\
\hline $1-1012$ & Norden i Fokus & 4.837 & 4.766 \\
\hline $1-1030$ & Hallo Norden & 6.695 & 6.596 \\
\hline $1-1036$ & Grænsehindringer i Norden & 5.137 & 5.061 \\
\hline $1-1050$ & Tjänstemannautbyte & 1.212 & 1.194 \\
\hline $1-2534$ & Bidrag til Nordisk sommaruniversitet (NSU) & 1.243 & 1.225 \\
\hline & Ministerrådets sekretariat (NMRS) & 80.433 & 79.244 \\
\hline $1-0180$ & Ministerrådets sekretariat (NMRS) & 80.433 & 79.244 \\
\hline
\end{tabular}


TDKK

Budget Budget $2018 \quad 2017$

Internationalt samarbejde (MR-SAM)

$60.657 \quad 55.261$

1-0820 Nordens närområdessamarbete

$30.677 \quad 17.876$

1-0980 Partnerskab og grænseregionalt samarbejde

$1.078 \quad 2.562$

1-0960 NGO-virksomhed i Østersøregionen

$0 \quad 6.548$

1-0810 Ministerrådets kontorer i Estland, Letland,

16.015

15.778

Litaven og Nordvestrusland

1-0850 Internationella aktiviteter

1.842

1.815

1-0870 Arktisk samarbeidsprogram

9.159

9.024

1-0950 Hvideruslandsaktiviteter

0

1-0990 Samarbejde med Nordens naboer i Vest

1.886

1.658

\begin{tabular}{|c|c|c|c|}
\hline TDKK & & $\begin{array}{c}\text { Budget } \\
2018\end{array}$ & $\begin{array}{c}\text { Budget } \\
2017\end{array}$ \\
\hline & Uddannelse og forskning (MR-U) & 221.338 & 221.541 \\
\hline & Generelle utdannings- og forskningsinnsatser & 3.427 & 3.376 \\
\hline $2-2505$ & Dispositionsmedel Utbildning och forskning & 3.427 & 3.376 \\
\hline & Politikudvikling m.v. & 15.954 & 15.718 \\
\hline $2-2544$ & Det nordiske sprogsamarbejde & 7.230 & 7.123 \\
\hline $2-2553$ & Politikudvikling, Videnssamfund og IT-infrastruktur & 585 & 576 \\
\hline 2-3127 & Politikudvikling voksnes læring & 8.139 & 8.019 \\
\hline & Mobilitets- og netværksprogrammer & 81.510 & 80.306 \\
\hline $2-2513$ & Nordplus & 75.931 & 74.809 \\
\hline $2-2515$ & Nordic Master Programme & 5.579 & 5.497 \\
\hline & Institution & 100.224 & 99.442 \\
\hline $2-3100$ & NordForsk & 100.224 & 99.442 \\
\hline & Forskning iøvrigt & 20.223 & 22.699 \\
\hline $2-3180$ & Nordisk Institut for Teoretisk Fysik (NORDITA) & 8.209 & 9.320 \\
\hline $2-3181$ & Nordiska Institutet for Sjörett (NIfS) & 2.447 & 2.778 \\
\hline $2-3182$ & Nordisk Institutt for Asiastudier (NIAS) & 3.878 & 4.403 \\
\hline $2-3184$ & Nordisk vulkanologisk institut (NORDVULK) & 3.963 & 4.498 \\
\hline 2-3185 & Nordisk Samisk Institutt (NSI) & 1.726 & 1.700 \\
\hline
\end{tabular}


TDKK

Budget Budget $2018 \quad 2017$

Kultur (MR-K)

$176.797 \quad 174.413$

Generelle kulturinnsatser

$51.637 \quad 51.496$

4-2203 Dispositionsmidler Kultur

711

974

4-2205 Nordisk kulturfond

36.088

35.555

4-2206 Nordisk Råds priser

$4.345 \quad 4.281$

4-2208 Strategiska satsningar

$10.493 \quad 10.686$

Barn och unga

$6.344 \quad 6.250$

4-2212 Nordisk Børne- og Ungdomskomité (NORDBUK)

6.344

6.250

Film och media

$32.222 \quad 31.846$

4-2222 Nordisk Film- och TV-fond

29.180

28.849

4-2228 NORDICOM

3.042

2.997

Konstområdet

31.760

31.820

4-2251 Kultur-og kunstprogrammet

16.756

16.813

4-2253 Nordisk oversættelsesstøtte

3.172

3.175

4-2254 Nordiskt-baltiskt mobilitetsprogram för Kultur

11.832

11.832

Nordiska kulturhus (institutioner)

48.144

46.010

4-2270 Nordens hus i Reykjavik

13.046

11.148

4-2272 Nordens hus på Färöarna

13.986

13.884

4-2274 Nordens institut på Åland

3.041

3.023

4-2277 Nordens institut på Grönland (NAPA)

6.555

6.507

4-2548 Nordisk Kulturkontakt

11.516

11.448

Andra kultursatsningar

6.690

6.991

4-2232 Övriga kulturverksamheter

2.741

3.100

4-2234 Samisk samarbeid

3.949

3.891

TDKK

Budget Budget

$2018 \quad 2017$

Ligestilling (MR-JÄM)

9.322

9.185

Projektmedel

$9.322 \quad 9.185$

6-4410 Projektmedel - Jämställdhet

3.670

3.616

6-4420 MR-JÄMs stödordning/jämställdhetsfond

2.986

2.942

6-4480 Nordisk information för kunskap om kön (NIKK)

2.666

2.627 


\begin{tabular}{|lrr|}
\hline TDKK & 2018 & \multicolumn{1}{c}{2017} \\
& $\mathbf{4 2 . 1 6 4}$ & $\mathbf{4 0 . 2 1 9}$ \\
$\begin{array}{l}\text { Fiskeri og Havbrug, Jordbrug, Levnedsmidler } \\
\text { og Skovbrug (MR-FJLS) }\end{array}$ & 953 & 939 \\
\hline 5-6420 Ny nordisk mad & 6.512 & 6.416 \\
\hline Fiskeri & 6.512 & 6.416 \\
5-6610 Projektmedel - Fiskeri & 28.823 & 27.074 \\
Jord- og skovbrug & 1.098 & 382 \\
5-6510 Projektmidler Jordbrug & 150 & 848 \\
5-6520 Nordiskt kontaktorgan för jordbruksforskning (NKJ) & 322 & 317 \\
5-6310 Projektmidler Skovbrug & 5.844 & 5.758 \\
5-6581 Samnordisk skogsforskning (SNS) & 21.409 & 19.769 \\
\hline Institutioner - jordbrug & 21.409 & 19.769 \\
5-6585 Nordisk Genressource Center (NordGen) & 5.876 & 5.790 \\
Levnedsmidler & 5.302 & 5.224 \\
5-6810 Projektmedel - Levnedsmidler & 574 & 566 \\
5-6830 Nordisk handlingsplan for bedre helse og livskvalitet & &
\end{tabular}

TDKK

\section{Social- og Helsepolitik (MR-S)}

Projektmedel

$\begin{array}{cc}\text { Budget } & \text { Budget } \\ 2018 & 2017\end{array}$

$43.290 \quad 39.363$

$23.629 \quad 19.280$

3-4310 Projekmedel - Social- och hälsovårdspolitik

$5.530 \quad 5.748$

3-4311 Nordisk helsesamarbejde

$3.336 \quad 1.287$

3-4312 Nordisk socialsamarbejde

3.350

3-4320 Rådet för nordiskt samarbete om funktionshinder

1.180

1.163

3-4340 Nomesko og Nososko

$1.988 \quad 1.959$

3-4382 NIOM AS - Nordisk institutt for Odontologiske

8.245

9.123

Materialer

Institutioner

19.661

20.083

3-4380 Nordens Välfärdscenter

$19.661 \quad 20.083$ 
TDKK

Bæredygtig Vækst (MR-VAEKST)

Näring

7-5140 Projektmidler Näring

7-5280 Nopef

Institutioner - Näring

7-5180 Nordic Innovation (NI)

Energi

7-5141 Projektmidler Energi

Institutioner - Energi

7-3220 Nordisk Energiforskning (NEF)

Regional

7-5143 Implementering av samarbeidsprogrammet

7-5151 NORA

7-5160 Grenseregionalt samarbeid

Institutioner - Regional

7-6180 Nordregio
Budget Budget

$2018 \quad 2017$

$132.402 \quad 129.080$

$86.557 \quad 85.664$

$1.529 \quad 2.056$

$15.375 \quad 15.698$

$69.653 \quad 67.910$

$69.653 \quad 67.910$

$13.213 \quad 10.322$

$3.934 \quad 4.276$

$9.279 \quad 6.046$

$9.279 \quad 6.046$

$32.632 \quad 33.094$

$6.786 \quad 5.507$

$6.728 \quad 6.858$

$8.237 \quad 9.615$

$10.881 \quad 11.114$

$10.881 \quad 11.114$
TDKK

Budget Budget $2018 \quad 2017$

Miljø og Klima (MR-MK)

$46.402 \quad 45.716$

8-3310 Dispositionsmidler Miljø

$4.240 \quad 4.686$

8-3311 Miljøsektorens arbejdsgrupper

8-3312 Nordisk Råds miljøpris

$25.326 \quad 24.443$

$848 \quad 835$

8-3320 NEFCOS Miljøudviklingsfond

$11.576 \quad 11.405$

8-6720 SVANEN - Nordisk miljömärkning

$4.412 \quad 4.347$


TDKK

Budget Budget $2018 \quad 2017$

\begin{tabular}{|llrr|}
\hline Arbejdsliv (MR-A) & $\mathbf{1 4 . 2 9 2}$ & $\mathbf{1 4 . 0 8 6}$ \\
\hline \multirow{2}{*}{$9-4110$} & Projektmedel & 10.784 & 10.625 \\
Projektmidler i øvrigt - Arbejdsliv & 1.080 & 1.064 \\
$9-4111$ & Arbejdsliv faste udvalg & 4.689 & 4.620 \\
$9-4120$ & Nordjobb & 3.321 & 3.272 \\
$9-4130$ & Kommunikation om arbejdsliv & 1.694 & 1.669 \\
\hline \multirow{2}{*}{ 9-4180 } & Institutioner & 3.508 & 3.461 \\
& Nordiska Institutionen för Vidareutbildning & 3.508 & 3.461 \\
& inom Arbetsmiljöområdet (NIVA) & & \\
\hline
\end{tabular}

\begin{tabular}{|llcc|}
\hline TDKK & & Budget & Budget \\
& & 2018 & 2017 \\
\hline $10-5210$ & Projektmedel- Ekonomi och finanspolitik & 1.598 & 1.874 \\
\hline
\end{tabular}

TDKK

Budget Budget $2018 \quad 2017$

Lovsamarbejde (MR-Lag)

$1.198 \quad 1.430$

11-7110 Projektmedel - Lagstiftning

$1.198 \quad 1.430$ 


\section{Bilag 1}

\section{De nordiske institutioners bevillinger}

i national valuta

\section{MR-U}

2-3100 NordForsk

123.733 .000

124.303 .000

NOK

\section{MR-S}

$\begin{array}{llrrl}\text { 3-4380 } & \text { Nordens Välfärdscenter (NVC) } & 25.534 .000 & 25.104 .000 & \text { SEK } \\ \text { MR-K } & & & & \\ \text { 4-2270 } & \text { Nordens hus i Reykjavik (NOREY) } & 210.419 .000 & 206.438 .000 & \text { ISK } \\ 4-2272 & \text { Nordens hus på Färöarna (NLH) } & 13.986 .000 & 13.884 .000 & \text { DKK } \\ 4-2274 & \text { Nordens institut på Åland (NIPÅ) } & 408.700 & 405.800 & \text { EUR } \\ 2-2277 & \begin{array}{l}\text { Nordens institut på Grönland } \\ \text { (NAPA) }\end{array} & 6.555 .000 & 6.507 .000 & \text { DKK } \\ \text { 2-2548 } & \text { Nordisk Kulturkontakt (NKK) } & 1.547 .800 & 1.536 .700 & \text { EUR } \\ \text { MR-FJLS } & & & \\ 5-6585 & \begin{array}{l}\text { Nordisk Genressource Center } \\ \text { (NordGen) }\end{array} & 27.804 .000 & 24.711 .000 & \text { SEK } \\ & & & \end{array}$

\section{MR-VAEST}

7-5180 Nordic Innovation (NI)

$85.991 .000 \quad 84.888 .000 \quad$ NOK

7-3220 Nordisk Energiforskning (NEF)

$11.456 .000 \quad 7.558 .000 \quad$ NOK

7-6180 Nordregio

$14.131 .000 \quad 13.893 .000$ SEK

MR-A

9-4180 Institut för vidareutb. inom

472.000

464.600 EUR arbetsmiljö (NIVA) 


\title{
Bilag 2
}

\author{
Valutakurser 2018 \\ $100 \mathrm{EUR}=744 \mathrm{DKK}$ \\ 100 ISK $=6,2 \mathrm{DKK}$ \\ $100 \mathrm{NOK}=81 \mathrm{DKK}$ \\ $100 \mathrm{SEK}=77 \mathrm{DKK}$
}

\section{Inflationssatser 2018}

Danmark 1,5\%

Finland $1,5 \%$

Island $\quad 2,7 \%$

Norge $\quad 1,3 \%$

Sverige $\quad 1,71 \%$

Omregningsfaktoren for projekt-

midler er $1,5 \%$ 
Nordisk Ministerråd

Nordens Hus

Ved Stranden 18

1061 København K

www.norden.org

ANP 2018:724

ISBN 978-92-893-5415-8 (PRINT)

ISBN 978-92-893-5416-5 (PDF)

ISBN 978-92-893-5417-2 (EPUB) 